\title{
Cultura popular no planejamento e na prática de professores dos anos iniciais do ensino fundamental
}

\section{Popular culture for planning and practice of teachers during the early years of elementary education}

\section{Cultura popular en la planificación y la práctica de profesores de los primeros años de la educación fundamental}

\author{
Edinaldo Medeiros Carmo* \\ Rosa Belém Farias* \\ Marco Antonio Leandro Barzano ${ }^{* * *}$
}

\section{Resumo}

Este artigo traz o resultado de uma pesquisa realizada durante um curso de mestrado no Programa de Pós-graduação em Educação da Universidade Estadual do Sudoeste da Bahia. A investigação partiu de inquietações relacionadas à abordagem da cultura popular no currículo da escola, especificamente, nos anos iniciais do Ensino Fundamental. Trata-se de uma pesquisa de natureza qualitativa, cujo objetivo foi compreender como a cultura popular é abordada nos documentos curriculares. Além disso, utilizou-se a entrevista semiestruturada com quatro professoras que relataram suas práticas pedagógicas. Os resultados demonstraram que as professoras, no desenvolvimento do currículo, utilizam astúcias e modos sutis para abordar a cultura popular em suas aulas, desencadeando um processo de criação e invenção na prática. As narrativas das professoras demonstram, ainda, que, ao planejarem suas aulas, introduzem dispositivos didáticos que permitem gerar discussões sobre a cultura popular e implantam ações como: visitas a pontos da cidade que são referências, entrevistas com representantes da cultura local, etc., para que a temática não fique nas margens do currículo desenvolvido na escola.

Palavras-chave: Cultura. Currículo. Escola.

Recebido em 08/04/2020 - Aprovado em 30/09/2020

http://dx.doi.org/10.5335/rep.v27i3.12383

Doutor em Educação pela Universidade Federal Fluminense. Professor do Departamento de Ciências Naturais - Universidade Estadual do Sudoeste da Bahia. Orcid: https://orcid.org/0000-0002-1594-8983. E-mail: medeirosed@uesb. edu.br

** Mestre em Educação pela Universidade Estadual do Sudoeste da Bahia. Professora da Rede Municipal de Ensino de Carinhanha, Bahia. Orcid: https://orcid.org/0000-0003-3824-2032. E-mail: belemcnn@hotmail.com

*** Doutor em Educação pela Universidade Estadual de Campinas. Professor do Departamento de Educação - Universidade Estadual de Feira de Santana. Orcid: https://orcid.org/0000-0003-3273-9216. E-mail: marco.barzano@gmail.com 


\section{Abstract}

This article shows results of a research derived from a master's course in the Postgraduate Program in Education of the State University of Southwest Bahia. The investigation was originated from concerns linked to the popular culture's approach in the school curriculum and especially in the early years of Elementary School. It is a qualitative research aimed to understand how popular culture is approached in the curriculum documents. In addiction, a semi-structured interview with four teachers reporting their pedagogical practices was used. The results showed that teachers use clever and subtle ways in the development of the curriculum to approach popular culture in their classes, triggering a process of creation and invention in practice. The teachers' narratives also demonstrate that they introduce didactic devices in the planning of their classes, allowing to generate discussions regarding popular culture and implementing actions such as visits to points of the city that are references, interviews with representatives of the local culture and others avoiding to let this topic to stay on the margins of the curriculum developed at the school.

Keywords: Culture. Curriculum. School.

\section{Resumen}

Este artículo muestra el resultado de una investigación realizada durante un curso de maestría en el Programa de Posgrado en Educación de la Universidad Estatal del Suroeste de Bahía. La investigación se originó en las preocupaciones con los maestros y profesores relacionadas con el enfoque de la cultura popular en el currículo escolar y específicamente en los primeros años de educación fundamental. Es una investigación cualitativa, con el objetivo de comprender el abordaje de la cultura popular en los documentos curriculares, utilizando además entrevistas semiestructuradas con cuatro docentes que informaron sobre sus prácticas pedagógicas. Los resultados muestran que los maestros y profesores utilizan formas astutas y sutiles en el desarrollo del plan de estudios para acercarse a la cultura popular en sus clases, desencadenando un proceso de creación e invención en la práctica. Las narrativas docentes demuestran también que, al planificar sus clases, introducen dispositivos didácticos que les permiten generar discusiones sobre cultura popular e implementar acciones tales como: visitas a puntos de la ciudad que son referencias, entrevistas con representantes de la cultura local y otros, con el fin de que este tema no quede al margen del plan de estudios desarrollado en la escuela.

Palabras clave: Cultura. Plan de estudios. Escuela.

\section{Introdução}

Este texto traz dados de uma investigação realizada durante o curso de mestrado no Programa de Pós-graduação em Educação da Universidade Estadual do Sudoeste da Bahia, que partiu de inquietações relacionadas à abordagem da cultura popular no currículo da escola, especificamente nos anos iniciais do Ensino Fundamental. Desse modo, tinha-se a inquietação de investigar como a cultura popular é abordada nos documentos curriculares e nas narrativas ${ }^{1}$ dos professores. Nessa perspectiva, os diálogos sobre a prática pedagógica e o currículo têm se tornado bastante complexos, demonstrando assim, que a educação é um campo em disputas. Neste estudo, buscamos compreender como professores, frente ao sentido que lhes atribui, materializam o currículo em sala de aula. 
Desse modo, falar de educação é, sem dúvida, conectar-se aos múltiplos diálogos, é pensar em diversidade, mas, para tanto, é preciso eleger alguns aspectos importantes de discussão e um deles é o currículo. Ainda, pensar a diversidade é também envolver a prática pedagógica nesse conjunto de ações que a apresenta como o diferencial, pois, no processo da escolarização, a prática pedagógica configura-se como uma ação potente que possibilita a abordagem da diversidade e da diferença. Em função dos novos enfoques educacionais, estudos têm mostrado que a construção do conhecimento perpassa por diversas engrenagens, contudo, mesmo não sendo o único, o currículo é um dos elementos mais investigados.

Partindo desse pressuposto, Goodson (2013) afirma que o currículo não pode ser o único instrumento de pesquisa no processo de escolarização, pois, a prática pedagógica também se constitui objeto muito importante nesse cenário produtivo. Portanto, essa prática, no contexto educacional, torna-se o aspecto essencial no processo de ensino, porque, é através dela que o conteúdo ganha forma. Nas colaborações de Schwille (1982, apud SACRISTÁN, 2000, p. 175), o docente tem participação importante nesse processo, pois, o professor, “[...] em última instância, decide os aspectos a serem desenvolvidos na classe, especificando quanto tempo dedicará a uma determinada matéria, que tópicos vai ensinar, a quem os ensina, quando e quanto tempo conceder-lhes-á e com que qualidade serão aprendidos”.

Assim, a prática pedagógica e o professor como mediador dela, são essenciais no processo da escolarização. Afinal, é o professor que, nas observações diárias, conhece e reconhece as potencialidades e fragilidades dos alunos. Portanto, conhece as vivências e as experiências deles. Nesse aspecto, o professor tem grande responsabilidade, pois, conforme destaca Santos (2000, p. 57), “[...] as experiências dos alunos, seus conhecimentos e sua inserção cultural, são aspectos a serem considerados nas práticas pedagógicas".

Embora o conceito de currículo seja multifacetado, há um consenso quanto ao seu valor e importância no cenário educacional. Para Moreira e Candau (2007, p. 19),

Currículo é, em outras palavras, o coração da escola, o espaço central em que todos atuamos, o que nos torna, nos diferentes níveis do processo educacional, responsáveis por sua elaboração. O papel do educador no processo curricular é, assim, fundamental. Ele é um dos grandes artífices, queira ou não, da construção dos currículos construídos que sistematizam nas escolas e nas salas de aula.

Assim, de acordo com Moreira e Silva (2013), o currículo é lugar que, ativamente, mediante tensões, produz e reproduz culturas. Currículo refere-se, nessa pers- 
pectiva, à criação, recriação, contestação e transgressão. Portanto, as mudanças no cotidiano escolar partem das ações pedagógicas, dos Projetos Políticos Pedagógicos escolares e devem posicionar-se frente ao ensino mais dialógico, na perspectiva reflexiva do currículo. Assim, Sacristán (2000) defende que o currículo é o espaço de construção e que a função dos professores não é somente executá-lo, pois eles têm um papel fundamental na produção dos seus significados. Com efeito, percebe-se que na ação docente as informações são articuladas a possíveis mudanças. Desse ponto de vista, acrescenta-se que a vida na escola se dá a partir da inter-relação professor-aluno, potencializando o exercício docente.

Nessa perspectiva, as interações que ocorrem no espaço escolar são permeadas por diferentes culturas. E, dando centralidade a dimensão empreendida nesta pesquisa, a cultura popular representa nos currículos escolares a resistência frente a gama de influências culturais advindas da globalização que reforçam a subalternização das culturas locais, tornando-se, ou querendo torná-las, culturas das margens. Assim, conforme adverte Chauí (2014, p. 27), “[...] não tentaremos abordar a cultura popular como uma outra cultura, ao lado (ou no fundo) da cultura dominante, mas como algo que se efetua por dentro dessa mesma cultura, ainda que para resistir a ela".

Por conseguinte, pensar em resistência é apontar os diferentes mecanismos de existência da cultura popular, passando pela luta política e pedagógica. Portanto, é reconhecer a essência e a importância da cultura para a vida humana. Desse modo, ressaltamos sua importância para que ela possa ser entendida como um vasto campo de conhecimentos, porque nela estão embutidas marcas que envolvem práticas diversas, nas quais se ensina e se aprende.

A cultura popular configura-se, desse modo, como um espetáculo que, na maioria das vezes, ocorre nas ruas como tantas manifestações que constituem a cultura popular brasileira. Para além disso, Gullar (1983, p. 23) destaca outro sentido, ao afirmar que "[...] a cultura popular é um movimento para a libertação do homem e só tem sentido na medida em que promover o homem não só como receptor, mas principalmente como criador das expressões culturais". Contudo, cabe considerar que nessas manifestações ocorre a cumplicidade entre as pessoas, criando vínculos de ações afetivas, o que também é educativo, pois, por meio da ludicidade, acessam as memórias e as afirmações de identidades.

Nesse sentido, a cultura popular é um movimento que atrai a presença significativa de pessoas, isso quer dizer que, mesmo com as mudanças ocorridas na sociedade, como as linguagens virtuais, os meios de comunicação, entre outros me- 
canismos tecnológicos, a cultura popular permanece e ainda resiste às influências desse momento histórico (FÁVERO, 1983). Contudo, a cultura popular permeia conversas e narrativas, talvez não no mesmo ritmo e vigor de outrora, principalmente entre os mais jovens. Por isso, insiste-se que a escola pode contribuir para o fortalecimento da cultura popular que, pelas ações de professores, militantes e defensores, insiste em não permanecer nas margens.

Diante disso, pela natureza qualitativa que a abordagem dessa pesquisa requer, buscou-se compreender como a cultura popular é abordada nos documentos curriculares e nas narrativas dos professores ao relatarem suas práticas pedagógicas. Para Minayo (2013, p. 57), esse tipo de estudo aplica-se ao “[...] estudo de história, das relações, das representações, das crenças, das percepções e das opiniões, produções das interpretações que humanos fazem a respeito de como vivem, constroem seus artefatos e a si mesmos, sentem e pensam”. Essa natureza de investigação pressupõe que não há como trabalhar com variáveis como tentativa de provar ou comprovar algo, e, nesse caso, compreender as narrativas dos professores parte do pressuposto de que não se pretende comprovar, pelo contrário, busca-se compreender nos resultados subjetivos, e, nessa direção, a pesquisa qualitativa comporta todos os parâmetros que corroboram para essa perspectiva.

O estudo foi realizado no município de Carinhanha, situado no oeste baiano, e teve como participantes quatro professores, selecionados mediante os seguintes critérios: a) professores com vínculo efetivo; b) professores que lecionam com turmas do $4^{\mathrm{o}}$ e do $5^{\mathrm{o}}$ ano do Ensino Fundamental; c) professores de duas escolas municipais, sendo uma na zona urbana e a outra na rural. As fontes de produção de dados consistiram em documentos curriculares (Projeto Político Pedagógico, planos de ensino, projetos didáticos etc.), além de entrevista semiestruturada, realizada com as quatro professoras que participaram do estudo.

Os dados obtidos por meio da análise dos documentos curriculares, produzidos pelas professoras na escola, assim como, os oriundos das entrevistas, foram avaliados mediante Análise de Conteúdo. De acordo com Bardin (2011), a Análise de Conteúdo é um aparato de instrumentos ressignificáveis, capaz de se reinventar mesmo diante do tempo e das transformações sociais, políticas e culturais. Para Olabuenaga e Ispizúa (1989 apud MORAES, 1999), a Análise de Conteúdo é uma técnica de leitura interpretativa de toda classe de documentos, que, analisados adequadamente, abrem as portas ao conhecimento de aspectos e particularidades dos dados da vida social do outro, que, na maioria das vezes, são inacessíveis. Desse modo, essa técnica, na perspectiva qualitativa, parte de uma série de pressu- 
postos, os quais, no exame de um texto, servem de suporte para captar seu sentido simbólico. No entanto, esse sentido nem sempre é manifesto e o seu significado não é único, o que indica que este poderá ser compreendido em função de diferentes perspectivas.

\section{Planejamento e suas interfaces com a cultura popular: do planejado ao vivenciado}

Os diálogos sobre a prática pedagógica e o currículo têm se mostrado bastante complexos. Desse modo, em meio aos acirramentos nos contextos social, político e educacional, o professor torna-se um dos principias protagonistas no que diz respeito à sua compreensão sobre o currículo e à materialização deste em sua prática. Partindo desse pressuposto, focaliza-se, na análise apresentada, o papel do professor, frente ao sentido que se lhes atribui, ao materializam o currículo em sala de aula.

As narrativas das professoras foram semelhantes quanto ao trabalho com a cultura popular. Para todas as entrevistadas, desenvolver atividades relacionadas à cultura popular tem sido muito desafiador. Foram relatos que caracterizam dificuldades, seja pela falta de direcionamento dessa temática no currículo, pois este pouco orienta o trabalho docente, seja por questões relacionadas à formação, e, não menos importante, às cobranças insistentes por resultados e à centralidade aos conteúdos. Frente aos relatos das professoras, abordar a cultura popular em sala de aula exige iniciativa e resistência. Tal justificativa dá-se pelas restrições do próprio currículo. Refutar, renunciar alguns dos muitos imperativos prescritivos, exige muita ousadia na prática pedagógica. Portanto, relutar com as muitas ordenações curriculares exige do professor atitude e, ao mesmo tempo, leva-o a correr riscos.

Assim, ao questionar as professoras sobre a materialização do currículo por meio do planejamento e as mudanças que ocorrem nessa transposição, a professora Júlia destaca:

São várias mudanças, desde nosso olhar ao exposto, até articularmos tudo aquilo em um plano e, por fim, transformar em aula. Confesso que são muitas interpretações. Mas, às vezes, estas mudanças nos custam muito caro, porque nem sempre as mudanças são bem-vindas na escola. Somos orientados a cumprir fielmente a cartela dos conteúdos, e muitos dos guias não trazem a cultura popular. 
Ao analisarmos essa narrativa, cabe considerar que, sem dúvidas, romper com regras estabelecidas ou, até mesmo, criar outros procedimentos, os quais são elencados como mais adequados e decisivos, tira o professor, em muitos casos, da sua zona de conforto. Conforme observa Freire (2002), é na inquietação, na incompletude, que nos tornamos criteriosos e exigentes. A atitude da professora mostra seu compromisso com o aluno, demonstra também que a interpretação e reinterpretação do currículo são fomentadas por outras produções do conhecimento que são extremamente importantes para a formação dos discentes; nesse sentido, em muito dos casos: "O currículo recai em atividades escolares, o que não significa que essas práticas sejam somente expressão das intenções e conteúdos do currículo" (SACRISTÁN, 2000, p. 201).

É imperativo, nesse sentido, observar cuidadosamente as sutilezas dos esquemas utilizados para difundir as ideologias dominantes transmitidas pelo currículo. Essa transmissão ocorre por vários veículos, desde a ausência de esquemas representativos, até o livro didático, material comumente utilizado pelos professores e alunos das escolas. E, nesses materiais didáticos está embutida uma linguagem que, cotidianamente, vai materializando a ideologia e os interesses de grupos sociais dominantes, com base apenas num fundamento social, político e cultural (MOREIRA; SILVA, 2013).

Porém, algo também chama a atenção, quando a professora Julia expõe a vigilância que é direcionada ao professor e à sua prática para abordar os conteúdos prescritos no currículo. Mas, ainda na explicação da professora Júlia, entendemos porque é tão difícil para os professores buscarem outros percursos pedagógicos.

Há uma política arraigada do copiar e colar. Digo isto porque falam de autonomia, mas nós sabemos que a escola é um sistema, e este, por sua vez, é orientado por outros meios. Então, nos últimos anos, a cobrança pelos conteúdos, resultados de avaliações [externas] ficam em primeiro lugar. E, para chegar a estes resultados, há toda uma orientação. Então, nós, de certa forma, somos monitorados. Se trabalhamos de outra forma, assumimos riscos. E é isto o que acontece, nos arriscamos sempre (Professora Júlia).

Analisando a narrativa da professora Julia depreende-se que há uma gama de exigências aos professores, sejam elas isoladas ou não, pelas quais o professor está sempre acarretado e também sob o controle interno e externo a escola. As ponderações de Sacristán sobre as competências do professor na hora de interpretar o currículo podem elucidar a narrativa de Júlia. Para Sacristán (2000, p. 204): 
O comportamento profissional destes [os professores] está muito mediatizado pela pressão em ter de atuar, constantemente, sendo exigidos pelas urgências de um ambiente que requer que um grupo numeroso de alunos se mantenha ocupado, dando cumprimento às exigências do currículo, às normas sociais da escola, etc.

Oportunamente, as reflexões de Sacristán (2000) denunciam com muita clareza as dificuldades vividas pelos professores, quanto à ideia de mobilizar o debate sobre a cultura popular, em um campo marcado pelo controle técnico, legitimadas pelas deliberações oficiais. Portanto, é preciso levar em conta o empenho, mas, também, por onde as atitudes astuciosas dos professores percorrem para materializar ou reconfigurar as prescrições curriculares.

Diante disso, a professora Olívia explica de que forma são feitas essas reconfigurações a partir do currículo. Enfaticamente, ao falar do Projeto Político Pedagógico, a professora demonstra sua insatisfação ao relatar que as entrelinhas ocupam um lugar incerto sobre a cultura popular. Grosso modo, ela tenta reordenar, reler o currículo articulando o contexto da escola e da comunidade, mesmo que esse esteja "vago" quanto aos repertórios dos saberes locais. Isso mostra que a professora, mesmo sentindo falta de uma maior explanação da temática no currículo, busca outros meios e possiblidades de inserção.

Entretanto, vale lembrar que no universo escolar, especificamente na sala de aula, o professor tem seu posicionamento quanto aos conteúdos abordados no currículo, os quais são identificados e rotulados como satisfatórios para a aprendizagem dos educandos. Contudo, cabe considerar que, assim, o currículo é produto de relações e disputas, nas quais estão contidos valores e posicionamentos de muitos, e o professor, por sua vez, também vem de um território no qual estão empregados valores e condutas que ele, na condição de intelectual, constrói e adquire durante sua trajetória social (APPLE, 2003).

Nesse sentido, podemos deduzir que esse profissional, ao interagir com o cotidiano da sala de aula, confabula situações, as quais o colocam diante de decisões em que ele precisa optar, ou não, por abordar determinados conteúdos prescritos no currículo. "Por isso, muitas das decisões que o professor tem de tomar aparecem como instantâneas e intuitivas, mecanismos reflexos, e, por isso mesmo, é difícil, se não impossível, buscar padrões para racionalizar a prática educativa enquanto esta se realiza" (SACRISTÁN, 2000, p. 205).

Contudo, apesar dos embaraços, os professores conspiram, vão silenciosamente reinterpretando, e os bloqueios vistos no currículo são confrontados com os saberes adquiridos ao longo da docência. Por isso, as contribuições da experiência 
profissional nesses momentos fazem a grande diferença em sala de aula. $\mathrm{O}$ relato da professora Olívia ratifica o que vem sendo discutindo. A professora reitera e avalia que:

[...] as ações [voltadas à cultura popular], [...] no projeto, falam de comunidade e a escola e vice-versa, [no entanto], vejo um tanto vago. Mas, pelas minhas experiências, organizo um planejamento no qual costumo desenvolver estratégias de conhecer pontos, algumas referências culturais da cidade. Vou à casa do Careta. Neste local, tem alguns registros importantes que precisam ser explorados e podem contribuir com a proposta sinalizada no Projeto Político Pedagógico. Também utilizo entrevistas com as pessoas da comunidade, dos movimentos sociais, dos grupos artísticos, pois eles são produtos vivos e grandes produtores [da cultura popular] (Professora Olívia).

Ao fazer referência à imprecisão do currículo, quanto à abordagem da cultura popular, Olívia também aponta os modos como, apropriando-se de sua experiência, modifica e implementa o planejamento curricular. Então, ao sinalizar os problemas no Projeto Político Pedagógico, procura intercalar outras fontes interativas para realizar atividades com os alunos. Desse modo, a professora demonstra certa destreza para desenvolver as atividades propostas. Possivelmente, a maturidade da profissão permite operacionalizar um leque de possiblidades que conduzem a professora a fomentar, sempre que oportuno, outros trabalhos sobre a cultura popular. E essa familiaridade marca seu modo de desenvolver o currículo, o que Freire (2002) denominou eixos temáticos para trabalhar com as vivências das classes populares. A professora Olívia ainda destaca:

Em meu plano de curso, trabalho por unidades, através das datas comemorativas. Eu sigo um tema, por exemplo, agora mesmo trabalharemos com o aniversário da cidade, aí aproveito o que pode ser implementado e ampliado sobre a cultura popular. As datas comemorativas são os pontos de partida (Professora Olívia).

O fragmento reporta e potencializa o valor da experiência profissional. Por meio dos saberes da experiência (TARDIF, 2002) o professor consegue produzir, orientar e desenvolver outras atividades. Nesse contexto, a inferência que fazemos é que a experiência adquirida possibilita ao professor refletir acerca dos efeitos sobre o processo do ensino e aprendizagem, e, a depender da sua atuação, podem potencializar a sua ação e a aprendizagem dos alunos, reconhecendo e valorizando os seus saberes e das suas comunidades.

Assim, segundo Olívia, a partir da sua autocrítica, as atividades fomentadas por ela não correspondem ao potencial cultural que o município possui. Para ela, a cultura popular deve ter um destaque perante a cultura da escola. Mas, contrariando o desejo da professora, a escola ressalta por meio das práticas sutis a visi- 
bilidade da política do mercado, a qual é representada pela cultura de massa que, como argumenta a professora, acaba secundarizando a cultura popular. De acordo com Forquin (1993), é injustificável na realidade atual desconsiderar a diversidade de identidades existentes na escola. A professora acrescenta:

[...] competir com este mercado, eu digo que é um dos grandes gargalos para nós, professores. Buscar neste momento, no qual é evidente uma produção momentânea das coisas, onde o que agora é, mais tarde já não é mais, representa um desafio e tanto. Mas, é também a partir das nossas reflexões, do nosso tato pedagógico, que iremos selecionar ou, ao menos, tentar inserir contextos de práticas sociais que possam contribuir com o processo da formação humana de cada um dos nossos alunos (Professora Olívia).

Ao analisar essa narrativa percebemos uma possiblidade de diálogo com o pensamento de Certeau (2014). Ao perceber que o currículo está distante da realidade sociocultural dos seus alunos, a professora, como diria o autor, utiliza "táticas", no intuito de encontrar outras itinerâncias. Nesse sentido, conforme assevera Certeau (2014, p. 38), "O cotidiano se inventa com mil maneiras de caça não autorizada".

Por meio do depoimento das professoras, é possível destacar que elas são as principais interessadas na inclusão da cultura popular no currículo da escola. Embora estejam presentes inúmeras situações contrárias, nos relatos de suas práticas pedagógicas demonstram o comprometimento com os saberes locais. Logo, pela maneira como tratam a cultura popular, a forma como reconhecem e tentam estabelecer interface entre o conhecimento popular e os conteúdos programáticos, é possível perceber um pequeno hiato, um rompimento com a sequência hierárquica do ensino, contudo, suas práticas vêm sugestionando os saberes "híbridos" (BHABHA, 1998).

Desse modo, as bricolagens ${ }^{2}$ (CERTEAU, 2014) das professoras denunciam também que o currículo não explicita possibilidades de abordar os elementos culturais, sobretudo aqueles relacionados à cultura popular. Isso, de sobremaneira, sobrecarrega o professor, pois ele tem que buscar modos "de caça não autorizada", como afirma Certeau (2014), para reconfigurar o currículo, buscando lacunas e oportunidades que o permita transgredir. A professora Olívia, por exemplo, reforça que, nessa luta, em que estão em jogo algumas prioridades, os professores acabam quase solitários.

O Projeto Político Pedagógico não é um documento de muita clareza. Quero dizer com isto que não há explanação sobre a cultura popular. E, por isso, é que, enquanto professora, vou com as minhas ideias encaixando algumas coisas que acho interessante falar. Às vezes, penso até que, se não estou errada em fazer isto, mas vou remando contra a maré. 
Ao expressar "vou com as minhas ideias encaixando algumas coisas que acho interessante falar", a professora, certamente, numa ação calculada, vai imprimindo suas marcas em um território "vigiado". Apesar do cuidado de não burlar as temidas imposições, a professora, em suas táticas sutis (CERTEAU, 2014), reelabora as prescrições. As produções realizadas pela professora assentam-se no que Certeau assinala como piratarias ou clandestinidade. "As ideias encaixadas" no currículo podem ser interpretadas de duas maneiras: a primeira é a de que currículo, por ocasião, é um produto de imposições, e a segunda é a de que, é a partir dessas imposições que os professores, astuciosamente, vão reinventando o cotidiano, em que o prescrito, no campo das práticas, os professores, astuciosamente, subvertem e reescrevem outras histórias.

No entanto, mesmo com intenções produtivas, os professores sentem-se culpados por algumas transgressões curriculares. Ainda que, pedagógica e didaticamente, as atividades não apareçam soltas, o poder que o currículo e a cultura escolar têm de cercear as suas práticas, deixa-os constrangidos.

Parece que o currículo tenta preparar os alunos apenas para o mercado de trabalho, instrumentalizá-los, esta é a palavra. E nós professores é que vamos, dentro das possiblidades, construindo este diálogo mais reflexivo sobre todos estes desafios que envolvem a sociedade (Professora Olívia).

Nesse sentido, a escola admite as interferências do mercado na manipulação da informação no incentivo ao consumo e ao imediatismo. Estes são pontos fortes de discussões em que, de um lado, temos uma cultura do consumo, da alienação, e, de outro, busca-se, talvez, repensar as ações enquanto sujeitos de direitos e deveres. Apresentar situações de ensino fundamentadas nos contextos socioculturais dos alunos, também é uma forma de resistência às imposições que chegam à escola.

Assim, Moreira e Silva (2013) denunciam que o currículo oficial ainda oferece "perigo" quanto às reproduções das forças dominantes, e, nesse sentido, os autores pontuam que a grande tarefa dos professores é, justamente, analisar esses itens com vistas a uma política que permita o combate às forças que norteiam o currículo, dificultando outras visões de mundo. Para os autores, essa vigilância ajudará os professores a visualizar panoramicamente o currículo, tornando-o campo cultural de construção e produção de sentido, terreno da luta pela transformação das relações de poder.

Entre os vários pontos que demandam o currículo, algo é primordial ao professor: ser vigilante e reflexivo acerca dos contextos educacionais, sociais e políticos, nos quais os alunos estão imersos. Desse modo, é importante ter presente o dis- 
cernimento para selecionar contribuições que, associadas ao processo de ensino e aprendizagem, melhor ofereçam aos alunos a oportunidade de conviver e pertencer a suas culturas. Diante dessas considerações, a professora Sizaltina acrescenta que:

Em muitas datas, não dá para encaixar a cultura popular, mas, em muitos outros conteúdos, aparecem oportunidades. Aí, às vezes, eu trabalho falando da cultura popular que nem eu mesma percebo. Preferencialmente, são os conteúdos, mas, se tiver uma oportunidade, como já disse, faço algumas atividades.

Cabe considerar, mediante relato da professora, que é pertinente avaliar como os professores utilizam o lugar que ocupam para resistir, transgredir e, enfim, promover os desdobramentos em relação à materialização do currículo. Assim, muitos professores criticam as imposições curriculares que chegam até eles, destacando a inadequação à realidade dos educandos, o que leva alguns a resistirem a essas formas padronizadas do conhecimento. Dessa forma, as astúcias (CERTEAU, 2014) utilizadas pelos professores passam a ser as grandes aliadas na hora de operacionalizar o currículo. Os modos pelos quais os professores enfrentam as imposições curriculares são diversos; suas ações são observadas desde a não execução até a criação de táticas (CERTEAU, 2014) produzidas para abordar o conteúdo.

Discutir esses pressupostos que estão ligados direta ou indiretamente à prática pedagógica é avançar e reconhecer que o professor, no processo da escolarização, é mais do que um mero receptor e executor dos programas escolares. Ele, se, por um lado, operacionaliza as prescrições, por outro, resiste a elas, modifica-as para atender a situações reais de ensino e às necessidades formativas de seus alunos. A professora Olívia, ao descrever sua prática, destacou o modo como articula os conteúdos curriculares com os elementos da cultura popular.

[...] se eu estiver trabalhando com língua portuguesa - produção textual - gosto muito de inserir o cordel, parlendas, cantiga de roda, trava-língua, e isto tem dado muito resultado. Quando trabalho com história, procuro abordar os costumes da comunidade, por exemplo. Quando trabalhei o texto "bonecas", relatamos sobre as produções, como era feita na região, como se brincava, [problematizando], quem não tinha acesso às bonecas produzidas na indústria, brincava com quais tipos de bonecas? Vou inserindo questionamentos que direcionam para as práticas da cultura popular. Também trabalhamos as questões raciais, e o fio condutor é a cultura popular. Eu mexo muito com a cultura desses meninos, acho importante falar sobre isto. Acho muito importante falar sobre as preciosidades que revelam muito sobre nossa história.

O depoimento da professora Olívia, de certo modo, demonstra que, perante as imposições curriculares, ela tem articulado, astuciosamente (CERTEAU, 2014), os conteúdos disciplinares das séries em que leciona com os elementos da cultura 
popular local, incorporando, inclusive, um olhar crítico no que se refere ao acesso a bens materiais, questões raciais, valorizando a cultura enquanto identidade. Destarte, Forquin (1993, p. 9), ao analisar os conteúdos a serem ensinados na escola, destaca que

[...] toda crítica envolvendo a verdadeira natureza dos conteúdos ensinados, sua pertinência, sua consistência, sua utilidade, seu interesse, seu valor educativo ou cultural, constitui para os professores um motivo privilegiado de inquieta reação ou dolorosa consciência.

Nesse sentido, regido pelas escolhas que realiza no processo educativo, o professor é um mediador fundamental, no entanto, lhe cabe também ter parâmetros e critérios para suas escolhas e decisões. Forquin (1993) busca esse ponto de confronto entre os conteúdos a serem ensinados e o processo educativo. Assim, o autor considera importante a problematização e a reflexão sobre as questões culturais e as escolhas educativas. Ao relatar sobre as adversidades que atravessam o trabalho docente, a professora Raimunda destaca o quanto, algumas vezes, é tomada pelo desânimo, por insistir com a abordagem da cultura no currículo escolar.

Tem horas que, sinceramente, penso em desistir. Falo assim: se o currículo tem dificuldade de viabilizar este compromisso, por que eu, que já tenho tanto trabalho, vou insistir em algo que muitos não estão nem aí? Mas volto atrás e, às vezes, conversando com minhas colegas que me dão força para não deixar de lado. É assim mesmo, a gente fala as coisas no calor, mas é porque também não tem muito incentivo.

Considerando o esforço das professoras, mais uma vez, reconhece-se e ressalta-se que elas, por meio da atividade docente, são persistentes, mesmo quando o território é regido por regras educativas que conspiram contra sua atuação; e, nesse caso, Certeau (2014) argumenta que os sujeitos podem, em determinado momento, ter a chance de problematizar, barulhar a ordem dominante, dar golpes, e, onde a situação parecia inabalável e homogênea, as criatividades das práticas cotidianas, revertem situações dominadoras, em situações favoráveis. Em consonância com esse argumento, Sacristán (2000) avalia a atuação do professor frente às decisões políticas e pedagógicas e defende que esses profissionais, por meio de sua prática, reinterpretam tanto o currículo quanto as situações que os colocam em desafios.

[...] na hora de materializar este currículo são postos os desafios. Primeiro que o ponto forte são os conteúdos, e aí vêm as datas. Se eu fosse pegar ao pé da letra o que diz o currículo sobre a cultura popular, vou ser sincera, não trabalharia. Mas eu puxo algo daqui, puxo algo dali e surge muita coisa. Mas, alerto que, na prática, estou devendo, porque, no geral, são atividades ainda muito pontuais (Professora Raimunda). 
Narrativas como essa permitem considerar que os professores caminham na produção de novas epistemologias, embora, em muitos casos, não tenham consciência disso. Subvertem o currículo, imprimindo elementos pedagógicos para inserção de temáticas que julgam pertinentes serem abordadas com seus alunos. Numa primeira instância, as professoras reconhecem o que está previamente estabelecido no Projeto Político Pedagógico, no entanto, asseguram que no plano de curso, ao planejarem, articulam e incorporam os elementos da cultura popular apontados pontualmente nos documentos curriculares.

Eu acho que a maior discussão realmente acontece em sala de aula por meio do que eu sinalizo no plano de curso a partir de rodas de conversas, leituras, questionamentos e produções. Isto depende muito dos conteúdos expostos no PPP, porque seguimos as orientações. Mas o plano de aula é que apresenta esta temática. Nosso instrumento seguro para esta parte mais efetiva realmente é o plano de aula (Professora Olívia).

Fundamentadas no Projeto Político Pedagógico, as professoras, de modo astucioso, criam táticas (CERTEAU, 2014) para articular o prescrito e o emergente (cultura popular), traçando novas configurações curriculares. Ciente desses feitos é que as professoras, a despeito das imposições curriculares, ainda se sentem inspiradas para implementar sua prática e, consequentemente, melhorar o ensino. Portanto, fica claro que o ato de educar e suas implicações não se prendem ao exercício mecânico, muito menos, a uma atividade que se reduz ao treinamento. Porque, assim como Candau (2016, p. 807) assevera:

Não acreditamos na padronização, em currículos únicos e engessados e perspectivas que reduzem o direito à educação a resultados uniformes. Acreditamos no potencial dos educadores para construir propostas educativas coletivas e plurais. É tempo de inovar, atrever-se a realizar experiências pedagógicas a partir de paradigmas educacionais "outros", mobilizar as comunidades educativas na construção de projetos político-pedagógicos relevantes para cada contexto. Nesse horizonte, a perspectiva intercultural pode oferecer contribuições especialmente relevantes.

Os relatos apontam que as professoras não concorrem com o Projeto Político Pedagógico, pelo contrário, dentro de um espaço vigiado, criam táticas (CERTEAU, 2014) nos interstícios, nas frestas do planejamento para abordar a cultura popular em suas aulas. A professora Sizaltina ressalta:

[...] muitas vezes nos valemos das nossas insistências, do nosso plano de aula. [...] nesse sentido, o professor todos os dias faz enfrentamentos com ele mesmo por desafiar os limites da sua prática, e isto envolve uma série de fatores, desde a mediação entre o Projeto Político Pedagógico e o plano de sala de aula, até intermediar a recepção dos alunos quanto ao que é ensinado e também do seu desejo. 
Mediante as narrativas que compuseram esta análise, vale ressaltar os "modos de fazer" (CARMO, 2013) produzidos pelas professoras para imprimir no currículo os aspectos da cultura que as aproximavam da realidade sociocultural de seus alunos. De certo modo, elas reconhecem que a prática pedagógica é o fio condutor entre as prescrições curriculares e as suas intenções pedagógicas na sala de aula. É nessa prática que arquitetam, constroem e executam as diversas atividades, a fim de associar a cultura popular com os conteúdos propostos no currículo.

\section{Considerações finais}

A intenção deste trabalho consistiu em compreender como a cultura popular é abordada nos documentos curriculares e nas narrativas de professores ao falarem sobre sua prática pedagógica. Assim, foi possível observar que as professoras no desenvolvimento do currículo utilizam astúcias e modos sutis para abordar a cultura popular em suas aulas, desencadeando um processo de criação e invenção na prática. Desse modo, investigar como elas produzem essas inventividades para driblar as prescrições que chegam à escola, é ouvir as vozes silenciadas no currículo praticado. Afinal, os documentos curriculares investigados, sobretudo, os Projetos Políticos Pedagógicos das escolas, demonstram que a cultura popular tem sido secundarizada.

Entretanto, as narrativas das professoras que participaram do estudo demonstram também que ao planejarem suas aulas, introduzem dispositivos didáticos que permitem gerar discussões sobre a cultura popular e implantam ações como, visitas a pontos da cidade que são referências, entrevistas com representantes da cultura local etc., para que a temática não fique nas margens do currículo desenvolvido na escola. Desse modo, construir epistemologias a partir da escuta desses profissionais quanto à materialização do currículo, permite conhecer aspectos do currículo que a análise documental, tão somente, não permitiria.

Assim, as nuances que envolvem a cultura popular, os documentos examinados e a prática pedagógica configuram-se um território de disputas. Embora a cultura popular esteja marginalizada nos documentos oficiais, há iniciativas no interior das salas de aulas, as quais, por forças das precisões, muitas vezes, são silenciadas, exigindo que as professoras rompam com seus próprios medos, inseguranças e constrangimentos para fugirem da retórica de que os conteúdos programáticos devem ser cumpridos. Desse modo, as inventividades das professoras 
constituem demarcações que, cotidianamente, revelam seus esforços para que a cultura popular ocupe lugar no currículo.

Nesse sentido, por trás da aparente calmaria das escolas, há um território de contestação e criação, muitas vezes silenciado pelos discursos retóricos da cultura de massa que reforçam a hegemonia e secundarizam a diferença. Assim, torna-se imprescindível o desenvolvimento de pesquisas que adentrem o interior das escolas para falar com ela, ouvindo os relatos dos professores, alunos, gestores e funcionários, pois, somente eles poderão revelar as nuances do currículo desenvolvido que não aparecem nos documentos.

\section{Notas}

1 Cabe considerar que o conceito de narrativa que adotamos nesse texto não se filia à perspectiva que a utiliza como dispositivo de produção de dados, mas, num entendimento lato sensu.

2 Certeau (2014) utilizou a noção de bricolagem para denominar o algo novo resultante da união de vários elementos culturais.

\section{Referências}

APPLE, M. W. Ideologia e Currículo. 3. ed. Porto Alegre: Artmed, 2003.

BARDIN, L. Análise de conteúdo. São Paulo: Edições 70, 2011.

BHABHA, H. K. O local da cultura. Trad. De Myriam Ávila, Eliana Lourenço de Lima Reis e Glaucia Renate Gonçalves. Belo Horizonte: Editora da UFMG, 1998.

CANDAU, V. M. (org.). Reinventar a escola. 7. ed. Petrópolis: Vozes, 2016.

CARMO, E. M. Saberes mobilizados por professores de Biologia e a produção do conhecimento escolar. 183 f. Tese (Doutorado em Educação) - Faculdade de Educação, Unniversidade Federal Fluminense, Niterói, RJ, 2013.

CERTEAU, M. A invenção do cotidiano: 1. Artes de fazer. 22. ed. Petrópolis: Vozes, 2014.

CHAUÍ, M. Conformismo e resistência. Homero Santiago (org.). Belo Horizonte: Autêntica; São Paulo: Fundação Perseu Abramo, 2014.

FÁVERO, O. Cultura popular e educação popular: memória dos anos 60. 2. ed. Rio de Janeiro: Graal, 1983.

FORQUIN, C. J. Escola e cultura: as bases sociais e epistemológicas do conhecimento escolar. Porto Alegre: Artes médicas, 1993.

FREIRE, P. Pedagogia da autonomia: saberes necessários à prática educativa. São Paulo: Paz e Terra, 2002.

GOODSON, I. Currículo, teoria e história. Petrópolis: Vozes, 2013. 
GULLAR, F. Cultura popular. In: FÁVERO, O. (org.). Cultura popular, educação popular: memória dos anos 60. Rio de Janeiro: Graal, 1983. p. 15-31.

MINAYO, M. C. S. O desafio do conhecimento: pesquisa qualitativa em saúde. 13. ed. São Paulo: Hucitec, 2013.

MORAES, R. Análise de conteúdo. Revista Educação, Porto Alegre, v. 22, n. 37, p. 7-32, 1999. Disponível em: https://edisciplinas.usp.br/pluginfile.php/4125089/mod_resource/content/1/Roque-Moraes_Analise\%20de\%20conteudo-1999.pdf. Acesso em: 25 maio 2019.

MOREIRA, A. F. B.; SILVA, T. T. Sociologia e teoria crítica do currículo: uma introdução. São Paulo: Cortez, 2013.

MOREIRA, A. F.; CANDAU, V. Indagações sobre Currículo: currículo, conhecimento e cultura. Brasília, DF: Ministério da Educação, Secretaria de Educação Básica, 2007.

SACRISTÁN, J. G. O currículo: uma reflexão sobre a prática. Porto Alegre: Artmed, 2000.

SANTOS, J. L. O que é cultura. 14. ed. São Paulo: Loiola, 2000.

TARDIF, M. Saberes docentes e formação profissional. 4. ed. Rio de Janeiro: Vozes, 2002. 